Columbia Law School

Scholarship Archive

2014

\title{
The Salience of Social Contextual Factors in Appraisals of Police Interactions with Citizens: A Randomized Factorial Experiment
}

\author{
Anthony A. Braga \\ anthony_braga@ksg.harvard.edu \\ Christopher Winship \\ cwinship@wjh.harvard.edu \\ Tom Tyler \\ tom.tyler@nyu.edu \\ Jeffrey Fagan \\ Columbia Law School, jfagan@law.columbia.edu \\ Tracey L. Meares \\ tracey.meares@yale.edu
}

Follow this and additional works at: https://scholarship.law.columbia.edu/faculty_scholarship

Part of the Criminal Procedure Commons, and the Law Enforcement and Corrections Commons

\section{Recommended Citation}

Anthony A. Braga, Christopher Winship, Tom Tyler, Jeffrey Fagan \& Tracey L. Meares, The Salience of Social Contextual Factors in Appraisals of Police Interactions with Citizens: A Randomized Factorial Experiment, JouRnal of QUANTITATIVE CRIMINOLOGY, Vol. 30, P. 599, 2014; YALE LAW SCHOOL, PubLIC LAW Research Paper No. 506; Columbia LaW \& Economics Working Paper No. 471; Columbia Public Law RESEARCH PAPER No. 14-381 (2014).

Available at: https://scholarship.law.columbia.edu/faculty_scholarship/1849

This Working Paper is brought to you for free and open access by the Faculty Publications at Scholarship Archive. It has been accepted for inclusion in Faculty Scholarship by an authorized administrator of Scholarship Archive. For more information, please contact scholarshiparchive@law.columbia.edu. 


\title{
The Salience of Social Contextual Factors in Appraisals of Police Interactions with Citizens: A Randomized Factorial Experiment
}

\author{
Anthony A. Braga • Christopher Winship • Tom R. Tyler • \\ Jeffrey Fagan - Tracey L. Meares
}

(C) Springer Science+Business Media New York 2014

\begin{abstract}
Objectives Prior research indicates that public assessments of the manner in which the police exercise their authority are a key antecedent of judgments about the legitimacy of the police. In this study, the importance of context in influencing people's assessment of police wrongdoing is examined.

Methods A randomized factorial experiment was used to test how respondents perceive and evaluate police-citizens interactions along a range of types of situations and encounters. 1,361 subjects were surveyed on factors hypothesized to be salient influences on how citizens perceive and evaluate citizen interactions with police. Subjects viewed videos of actual police-citizen encounters and were asked for their evaluations of these observed encounters. Contextual primes were used to focus subjects on particular aspects of the context within which the encounter occurs.

Results Structural equation models revealed that social contextual framing factors, such as the climate of police-community relations and the legality of the stop that led to the encounter, influence citizen appraisals of police behavior with effects comparable in size to and even larger than demographic variables such as education, race, and income.

Conclusions These results suggest that the understandings and perceptions that people bring to a situation are important determinants of their assessment of police fairness. The
\end{abstract}

\author{
A. A. Braga \\ Rutgers University, Newark, NJ, USA
}

A. A. Braga $(\bowtie) \cdot$ C. Winship

John F. Kennedy School of Government, Harvard University, 79 John F. Kennedy Street, Cambridge, MA 02138, USA

e-mail: Anthony_Braga@harvard.edu

T. R. Tyler · T. L. Meares

Yale University, New Haven, CT, USA

J. Fagan

Columbia University, New York, NY, USA 
police can positively influence citizen interpretations of police actions by striving to create a climate of positive police-community relationships in cities.

Keywords Police legitimacy $\cdot$ Procedural justice $\cdot$ Priming $\cdot$ Randomized factorial experiment

\section{Introduction}

A growing body of research focuses on the legitimacy of the police-how it is constituted, when it is conferred, and what are the consequences of giving the police legitimacy or withdrawing it on the part of interested residents (Skogan and Frydl 2004; Tyler 2006). Legitimacy here means more than simply popular support. Rather, it is a deeper and complex notion that takes into account not only public support but also public willingness to recognize and defer to official authority. Legitimacy is the public belief that there is a responsibility and obligation to voluntarily accept and defer to the decisions made by authorities (Parsons 1967; Sarat 1977; Beetham 1991). Police need the support and cooperation of citizens to be effective in dealing with crime problems and maintaining social order in public spaces (Reisig 2010; Tyler 2004). Social contextual issues, such as the climate of police-community relations and the lawfulness of prior police actions, contribute to public assessments of the legitimacy of police departments and the rightfulness or wrongfulness of the immediate actions of particular officers (Skogan and Meares 2004; Tyler 2006).

Researchers in cognitive and social psychology suggest pre-existing social contextual knowledge can affect individuals' processing of ambiguous information (Fiske and Taylor 1991; Balcetis and Lassiter 2010). "Priming" is an implicit memory effect in which exposure to a stimulus influences a response to a later stimulus (Erdley and D'Agostino 1988; Higgins et al. 1985). Individual interpretation of information often depends on the particular knowledge structures (e.g., concepts and schemas) that are active when exposed to an ambiguous stimulus. People primed with varying social contextual factors can react very differently to an identical stimulus. For police departments, this suggests that social contextual factors shape citizen evaluations of police behavior even when people see the same event. As such, citizen assessments of the wrongfulness or rightfulness of particular police actions may be powerfully dependent on pre-existing knowledge structures that are positive or negative towards the police.

We used a randomized factorial experimental design and structural equation models to examine the influence of varying social contextual factors on individuals' assessments of the appropriateness of police interactions with citizens. In the factorial experiment, subjects viewed three real-life videos of police-citizen interactions presented in counterbalanced order. Prior to viewing the videos, subjects were randomly allocated positive, neutral, and negative descriptions for four social contextual issues: the climate of policecommunity relations in the city where the interaction takes place, the lawfulness of the police stop, the officers' prior history, and the citizens' prior history. Our analyses revealed that, although participants viewed identical videos, variations in the social contextual framing of the police-citizen interactions shown produced large and significant effects on subjects' ratings of police behavior in the video. 
This article begins by briefly reviewing the literature on police legitimacy and the salience of social contextual factors in individual appraisals of police behavior in interactions with citizens. The research design, data, and analytical framework are presented in subsequent sections. Results of the randomized factorial experiment and supporting structural equation model analyses are then detailed. The concluding section summarizes the research findings, frames the results within the existing literature on police legitimacy, and presents the implications of the research for police policy development and practice.

\section{Literature Review}

Police Legitimacy and Police Behavior

Policing communities, especially minority communities, always involves a delicate balance (Meares and Kahan 1998). On the one hand, research suggests that the police benefit from the general willingness of community members to cooperate with them to report crimes, identify criminals, assist in investigations, and address conditions that might facilitate crime (Moore 1992; Reisig 2010; Tyler and Fagan 2008). On the other hand, effective policing invariably involves tactics that bring the police into close and regular contact with community residents. This contact can be viewed by community residents, particularly minority residents, as intrusive and unwarranted, leading citizens to doubt whether the police respect their rights and care about their well being (Carr et al. 2007; Brunson and Miller 2006; Brunson and Weitzer 2009). Whether or not individuals have personal contact with police officers, their perceptions of the legitimacy of police have important consequences for police effectiveness (Tyler 2004, 2006). Policing is far more difficult without the support of the public. Therefore, police effectiveness is powerfully influenced by the consequences of different tactical and policy choices for their legitimacy.

Legitimacy is regarded as a view among the members of the communities involved that legal authorities play an appropriate role in making and implementing rules governing public conduct (Sunshine and Tyler 2003; Tyler and Huo 2002). Obviously, legal authorities can shape public behavior by virtue of their ability to use force and communicate the risk of sanctioning for noncompliance. However, in democratic societies the authorities rely heavily upon public willingness to voluntarily defer because they view the conduct of the police and courts as reasonable and just (Scheingold 1974; Easton 1975). These ethical qualities distinguish legitimacy from coercion, and reflect the idea that authorities have trust and confidence among the public, i.e. the view that people consider agents of social control to be acting on behalf of the community and exercising their authority in accord with principles of reasonable and appropriate conduct (Parsons 1967; Sarat 1977; Beetham 1991). Such feelings create legitimacy-the view that authorities ought to be deferred to and obeyed. It is such legitimacy, in turn, that leads to public cooperation with the police, cooperation that is central to their ability to manage crime and social disorder within communities (Tyler and Wakslak 2004).

It is obviously important to understand the factors that shape police legitimacy. One central focus of past research has been upon the strategies used by the police to manage crime (see, e.g. Braga 2008; Weisburd and Eck 2004). However, studies consistently suggest that public views about the police and the law are not simple reflections of the crime rate (Moore 2002; Tyler 2004). Recent discussions of policing acknowledge the important role that policing strategies have in shaping crime, but argue that attention needs to be given to a larger framework within which the influence of police actions on police 
legitimacy in the eyes of the public is also studied (Skogan and Frydl 2004). Such concerns have fueled a series of reforms in the manner in which legal authorities act, including community policing and neighborhood courts (Fagan and Malkin 2003).

Research suggests that the public evaluates police not only in terms of the ability of the police to fight crime (see, e.g. Moore 2002). People are also sensitive to the manner through which the police exercise their authority. As a consequence, the procedural justice of police actions is central to police legitimacy and policies such as racial profiling that are not evaluated to be just undermine police legitimacy (Fagan 2002; Tyler and Wakslak 2004). The issue of police behavior is very important in shaping the views of the public. Studies in the United States emphasize that both Whites and minority group members focus on the manner in which the police exercise their authority both when making general evaluations of the legitimacy of the police (e.g. Sunshine and Tyler 2003) and when reacting to personal experiences with the police (e.g. Tyler and Huo 2002).

Studies of personal encounters with the police consistently document that post-experience feelings are determined by the fairness in which the problem was handled. The National Research Council's Committee to Review Police Policy and Practices identifies four dimensions of fairness in police-citizen interactions (Skogan and Frydl 2004). First, citizens need to have meaningful participation in interactions. Importantly, citizens must have the ability to explain situations and communicate with the police. Second, citizens need to feel that the police officers were neutral in their assessments of situations by using objective indicators to make decisions rather than personal views. Third, citizens must feel that they were treated with respect and dignity by the police during interactions. Fourth, police officers need to inspire trust in the citizenry. If people believe authorities care about their well-being and are considerate of their needs and concerns, they view procedures as fairer. Police can encourage the public to view them as trustworthy by explaining their decisions and accounting for their conduct.

Tyler (2003) proposed a process-based model of police legitimacy that suggests a direct and measurable relationship between how police treat citizens and then, in turn, what citizens think of the police. Two related components are used to evaluate whether police practices are procedurally-just in the eyes of the public: quality of decision making (e.g., officers' use of objective indicators to make decisions) and quality of treatment (e.g., authorities treat citizens with dignity and respect) (Tyler 2003; Reisig et al. 2007). If the police are perceived to make fair decisions and to treat people respectfully, they will be viewed as legitimate authorities. As a result, the police will enjoy enhanced citizen cooperation and compliance with the law. A series of research studies have been found to support the key theoretical constructs in the process-based model of police legitimacy (see, e.g. Mastrofski et al. 1996; McCluskey 2003; Paternoster et al. 1997; Sunshine and Tyler 2003; Tyler and Fagan 2008; Tyler and Wakslak 2004).

Research has shown that other factors may also be quite important in stimulating citizen cooperation with the police. For instance, using survey data from the United States, Reisig et al. (2007) found that the fair distribution of police resources across individuals and neighborhoods (i.e., distributive fairness) was correlated with cooperation with the police and, using survey data from Ghana, Tankebe (2009) showed that perceived police crime control effectiveness was the main factor that determined citizen cooperation. Jackson and Bradford (2009) find that people think about their local police in ways less to do with the risk of victimization and more to do with judgments of social cohesion and moral consensus. Further, Jackson et al. (2012) found that people accept the police's right to dictate appropriate behavior not only when they feel a duty to obey officers, but also when they believe that the institution acts according to a shared moral purpose with citizens. Drawing 
on the work of Beetham (1991) and Coicaud (2002), Bottoms and Tankebe (2012) suggest effectiveness, distributive fairness, procedural fairness, and lawfulness as some of the likely main contents of the dimensions of police legitimacy in liberal democracies. Through an analysis of London survey data, Tankebe (2013) found empirical support for the relevance of these four dimensions to police legitimacy and that legitimacy has both a direct and an indirect influence on people's willingness to cooperate with the police.

Pre-existing opinions of the police strongly shape citizen perceptions of their interactions with the police (Brandl et al. 1994; Rosenbaum et al. 2005). People are suggested to form general impressions of the police before they have any personal contact with them; this, in turn, influences the nature of interactions between individuals and the police when such contact occurs (Hawdon 2008). Moreover, vicarious experiences, such as stories that people hear from their friends, family, and the media, influence the way citizens interpret and evaluate their own encounters with the police (Brunson 2007; Gallagher et al. 2001; Hohl et al. 2010; Weitzer and Tuch 2006). For instance, Warren (2011) found that people who hear negative stories about the police from family and friends are four times more likely to perceive disrespect during their own encounters with the police. In the next section, we more closely examine the potential importance of prior attitudes and expectations held by people in assessing police behavior in police-citizen encounters.

\section{The Salience of Social Contextual Factors in Assessing Police Behavior}

Many decades of psychological research has demonstrated that perceptions of events are shaped by the attitudes and expectations that people bring into the situation in which those events occur. So, different people can look at the same objective event and subjectively experience that event differently. People often remember the "facts" differently, as well as forming different inferences about the character and the intentions of those involved. In a classic demonstration of this phenomenon, Hastorf and Cantril (1954) interviewed psychology students from Dartmouth and Princeton after they observed the same football game. They were asked to evaluate what had happened and how fairly the players on each side played. Despite the fact the two groups had seen the same football game, there were large differences in both their evaluations of what had happened and their views about how fairly each side had played. Subsequent studies reinforce the suggestion that people's prior attitudes and values shape their understanding of the "facts" and their evaluations of and reactions to social situations (e.g., see Fiske and Taylor 1991).

Of course, perceptions may be simultaneously influenced by people's own ex ante attitudes and values; those factors may then interact with the characteristics of the social situations in which they are involved (Balcetis and Lassiter 2010). A particularly dramatic example of this phenomenon in a legal setting is provided in recent research on racial profiling (Tyler and Wakslak 2004). One question that has been studied is when people perceive themselves to be the victims of profiling. Research suggests that when they are treated disrespectfully by police officers during a street stop, minority group members are more likely to infer that they were stopped because of their race (Tyler and Wakslak 2004). And once they have made this inference about the police officer involved, people are likely to "remember" the facts of their experience in a manner consistent with this inference. In one study, analysis of videotapes of police-citizen encounters showed that motorists who had been stopped and had complained of being profiled remembered "facts," such as being called racially-tinged names (Sherman 1999). However, coding of the videotapes suggested that officers were interpersonally disrespectful but not overtly racist as the complaining motorists remembered. 
Psychologists have developed a variety of procedures for studying the influence of prior situational context upon the reactions of people with different attitudes and values to social situations. One of the most influential is priming (Bargh and Chartrand 2000). Priming involves the activation of particular aspects of a person's prior mental framework by presenting them with a brief set of stimuli designed to direct their thoughts and feelings in a particular manner. This presentation can evoke either conscious or automatic thought processes, but the key point is that it leads people to focus upon related thoughts. So, for example, by priming people with concepts such as adventurous or independent, we can lead them to form more positive evaluations of a person engaged in activities such as sailing across the world (Higgins et al. 1977). When police and probation officers were primed with racialized cues about hair, clothing and music styles (e.g., "dreadlocks, baggy jeans, hip hop"), the group that was "racially" primed attributed greater culpability to a racially ambiguous offender in a vignette about a convenience store robbery (Graham and Lowery 2007).

These "priors" also affect how people understand the "facts" in a given setting. As an example, eyewitness identification research makes clear that people's evaluations of others are shaped not only by the objective events they have witnessed, but also by their prior attitudes and values (Wells and Olson 2003). Further, studies suggest that the context within which people make evaluations shapes those evaluations (Fiske and Taylor 1991). When people are threatened by fear of crime, or have prior negative associations with the members of particular groups, these aspects of their mental frameworks shape their understanding of and reactions to events.

The procedural justice literature provides a related set of findings that suggests situational cues and framing effects may be important in affecting a person's evaluation of a situation. Previous research on a variety of law enforcement issues establishes that legal institutions gain and preserve legitimacy through adherence to procedural fairness norms (Tyler 2003, 2005). That is, judgments about the fairness of the manner in which these actors exercise their authority influence evaluations of legitimacy of the police and other legal actors in critically important ways. Such procedural justice judgments are found to both shape reactions to personal experiences with legal authorities and to be important in assessments based upon the general activities of the police (e.g., Paternoster et al. 1997; Reisig and Chandek 2001). In both instances, citizens view the police and courts as less legitimate when they personally experience or vicariously become aware of instances of unfair, disrespectful or unethical treatment-in other words, procedural injustice (Tyler 2004). Accordingly, experiences with the law and legal actors will shape attributions of the legitimacy of those actors and the institutions they represent.

There are many examples that illustrate this dynamic. For example, respectful and polite treatment by police reduces perceptions of racial profiling (Tyler and Wakslak 2004), and such treatment combined with officer efforts to explain the reasons for their actions translates into feelings of citizen satisfaction with police more generally (Skogan and Hartnett 1997; Tyler and Huo 2002). These legitimacy gains, in turn, translate into higher levels of respect for law and cooperation with law enforcement efforts. A large social science literature now examines these relationships and corroborates these findings in numerous distinct contexts (Tyler 2003; Tyler et al. 1997). Conversely, the lack of just legal and political procedures is found to motivate collective actions, such as riots, and to encourage people to become committed to crimes and even to extreme acts of terrorism (Krueger and Malechkova 2003; McCauley 2002).

Documenting these kinds of framing effects makes an important contribution to the existing literature on policing. The authors of a recent literature review on police-citizen 
relations conclude "there is no consensus as to which combinations of variables explain the greatest variance in attitudes toward the police" (Brown and Benedict 2002, p. 564). While the existing literature has explored individual-level demographic predictors, much less attention has been given to non-demographic factors such as the public's personal experiences and what people learn from the media and from friends (Gallagher et al. 2001). Similarly, the research regarding interactions among neighborhood or city conditions and evaluations of police is slim (Weitzer and Tuch 2006). We address some of these voids and add an important new dimension: situation-specific characteristics of encounters. Specifically, we assess the importance of situation-specific perceptions that are held just prior to viewing a situation in which police make an arrest. As we discuss in detail below, what we find is that differences in these immediate prior perceptions have effects that are as big as or bigger than demographic variables such as race, education, and income that have been the focus of prior research.

\section{Research Design and Data}

We used a randomized factorial experimental design to determine whether differences in social contextual framing factors produce variations in attributions of legitimacy to police during police-citizen encounters. A factorial experiment is a research design that consists of two or more factors that have discrete possible values or levels where the experimental units of analysis are distributed across all possible combinations of these levels (see Fisher 1926; Box et al. 2005). Factorial experimental designs allow the analysis of the effects of each factor on the outcome variable as well as interactions between these factors and the outcome variable. Subjects were first given a description of the context in which an arrest took place. The experimental manipulation randomly varied four social contextual factors: the description of the climate of police-community relations in the city in which the incident occurred; a description of the legal context of the police stop shown in the video, a description of the police officer involved; and a description of the citizen involved. After having been given a description of the context, subjects were then shown a set of three videos of actual police-citizen encounters and asked to evaluate the appropriateness of the observed police behavior. ${ }^{1}$ The goal of the experiment was to assess the degree to which peoples' judgments about police behavior can be influenced by how an incident is framed.

As will be described further below, subjects were exposed to the varying social contextual factors through a written script; they then viewed a video and responded to a battery of questions to measure the impact of these factors on their assessment of the police behavior viewed. The randomization of the social contextual factors mentioned in the written scripts was intended to ensure that the subjects in each of the factorial groups were equivalent. In general, when randomization is successfully achieved and the subjects in varying groups are equivalent, the estimation of treatment net effects can be simply expressed as the experimental group's score on an outcome measure minus the control group's outcome score (plus or minus stochastic effects; see Rossi et al. 2004). As part of this design, we collected additional data on a variety of dispositional variables and prior experiences for each subject to determine whether, the randomization of subjects among

\footnotetext{
1 Prior studies suggest the value of this type of vignette approach (Seron et al. 2006), but have used written vignettes of uncertain realism. We utilized actual videos of police interactions centered on the core issues in the study to supplement the vignettes and provide salient visual cues and contextual primes to stimulate respondents.
} 
the varying social contextual factors created equivalent factorial groups. These analyses, described below, confirmed that randomization was achieved and, reasonably equivalent groups were created.

It is important to note here that there are very few randomized controlled trials in this important area of policing research. A recent Campbell Collaboration systematic review of legitimacy policing concluded, "there is a clear lack of randomized experiments in the international research literature that specifically seek to isolate and test the component parts of a legitimacy policing intervention" (Mazerolle et al. 2012, p. 10). One noteworthy exception is the Queensland Community Engagement Trial which examined the direct and indirect outcomes of procedural justice policing under randomized field trial conditions. Relative to routine traffic stops in the comparison group, Mazerolle et al. (2013) found procedurally-just traffic encounters in the treatment group significantly shaped citizen perceptions of the actual encounter directly and general views of the police indirectly.

Randomized experimental designs have the advantage of strong internal validity-the extent to which a research design can eliminate competing explanations of an observed correlation (Shadish et al. 2002). However, randomized experiments are also noted to suffer from low external validity-the extent to which the findings of a study can be generalized to the population of interest. External validity of randomized experiments can be improved by drawing an initial sample that is representative of the population (Rossi et al. 2004). In this study, we were interested in making generalizations to urban populations. The study sample was constructed through a contractual arrangement with Knowledge Networks (hereafter, KN), a survey research firm based in Menlo Park, California that specializes in video-based surveys using the internet. KN retains a permanent sample of approximately 40,000 plus individuals from which subsamples can be drawn to carry out specific surveys. The KN panel sample is representative of the U.S. population, which allows for stratification and representation across demographic groups (Couper 2000; Dennis 2001). Recruitment into the KN panel takes place through a Random Digit Dialing (RDD) method to random samples of U.S. households. All members of the household are invited to participate in the panel. Surveys are answered electronically either over the PC or through a web-based TV connection. KN panel members receive free internet access and email accounts, including equipment if needed. $^{2}$

\footnotetext{
${ }^{2} \mathrm{KN}$ has completed several studies to validate its methodology, including both accuracy and nonresponse bias. For example, Krosnick and Chang (2001) compared responses to a single survey on the 2000 presidential election using three different samples and methods: KN, Harris Interactive (HI), and a RDD survey conducted by the Ohio State University Center for Survey Research. They reported that the KN samples had higher completion rates, closer approximation to census estimates, and less skew on basic measures of opinion and voting behavior. They also show higher measurement reliability and "non-differentiation" of responses for Internet-enabled data collection compared to RDD. Skitka and Mullen (2002) and Skitka et al. (2002) show that on questions of civic values and actions, in particular, telephone survey responses were more often influenced by respondents' motivations to present themselves in a positive light to interviewers compared to internet-enabled surveys. Benchmarking studies show that KN samples yield estimates for several health behaviors—current smoking, diabetes, ulcer, migraine headaches, and stroke—similar to the estimates in the National Health Interview Survey conducted by telephone annually by CDC. The average difference in the results is about 1 percentage point (Baker et al. 2003).
} 
Data

The study sample included KN panel members age 18 or older who lived in 15 U.S. cities. ${ }^{3}$ A total of 1,361 completed interviews were obtained, reflecting a $62 \%$ completion rate. $^{4}$ Respondents viewed three videos of citizen-police encounters presented in random order. After each video, the respondents completed a set of questions evaluating whether they believed that the police officer(s) in the video were wrong in their handling of the situation and deserved to be punished. It was critical to determine whether the effects of group membership, past experience with the police and crime, and general perceptions of the police, and other salient factors were significantly different among subjects in the groups randomly exposed to the varying social contextual framing effects. As such, each respondent also completed a questionnaire on their identification with the police, political ideology, trust in government, perceptions of police effectiveness in their neighborhood, perceptions of procedural justice in their most recent encounter with the police, prior crime victimization, disorder concerns in their neighborhood, and fear of crime in their neighborhood. ${ }^{5}$ This also allowed us to test whether the above factors continue to affect their evaluation of police behavior under experimental conditions.

Table 1 presents selected socio-demographic characteristics of the respondents. The $\mathrm{KN}$ panel members that participated in the study were mostly older than 30 years of age $(78 \%)$. Non-Hispanic whites $(59 \%)$ represented the largest racial group of respondents followed by Hispanics $(18 \%)$ and non-Hispanic blacks $(14 \%)$. The sample was evenly split between males and females. Slightly more than $34 \%$ of respondents had at least a bachelor's degree and only about $9 \%$ had less than a high school education. The sample was generally middle-class and higher with $33 \%$ having a yearly household income between $\$ 40,000$ and $\$ 75,000$ and nearly $41 \%$ having a yearly household income greater than $\$ 75,000$. Respondents were politically diverse as $36 \%$ described themselves as Independents, $34 \%$ described themselves as Democrats, and $27 \%$ described themselves as Republicans. Half of the respondents reported that a member of their household had been the prior victim of a property or violent crime. It is unfortunate that we were not able to obtain additional young, minority subjects. While our final sample was not completely representative of an urban population, we did obtain a diverse group of respondents that strengthened the external validity of our randomized factorial experiment.

\footnotetext{
${ }^{3}$ The 15 U.S. cities were Baltimore, Boston, Chicago, Cleveland, Denver, Detroit, Houston, Los Angeles, Miami, New York, Philadelphia, Phoenix, San Diego, Seattle, and Washington, DC. Knowledge Networks completed between 85 (New York) and 98 (Baltimore) interviews in each city.

${ }^{4}$ The survey was fielded on March 27, 2008 to a sample of 2,183 Knowledge Networks panel members. To be included in this analysis, a respondent had to view all three videos $(\mathrm{N}=1,361)$.

${ }^{5}$ These questions were randomly administered before or after the videos were viewed. 676 respondents completed the questionnaire after seeing the videos and 685 respondents completed the questionnaire before seeing the videos. To investigate whether the timing of the administration of the questionnaire impacted our findings, we split the sample and replicated the full sample analyses presented here. When the impact of the four framing effects dummy variables (city climate of police-citizen relations, stop context, officer history, and citizen history) on the "police were wrong/should be punished" outcome variable were estimated, the two split samples produced coefficients of similar direction, magnitude, and statistical significance $(p<.05)$. As such, whether the respondent answered the questionnaire before or after the video did not substantively impact the findings presented in Tables 2,3 , and 4.
} 
Table 1 Selected socio-demographic characteristics of respondents

\begin{tabular}{|c|c|c|}
\hline Variable & Number & Descriptive statistics \\
\hline Age & 1,361 & $\begin{array}{l}\text { Mean }=46 \text { years, range }=1-88 \text { years } \\
\text { Less than } 30 \text { years old }=22.2 \%\end{array}$ \\
\hline Sex & 1,361 & $47.7 \%$ male, $52.3 \%$ female \\
\hline Race & 1,361 & $\begin{array}{l}\text { White, non-Hispanic }=58.6 \% \\
\text { Black, non-Hispanic }=14.3 \% \\
\text { Hispanic }=18.0 \% \\
\text { Other }=9.1 \%\end{array}$ \\
\hline Education & 1,361 & $\begin{array}{l}\text { Bachelor's degree or higher }=34.2 \% \\
\text { Some college }=26.7 \% \\
\text { High school }=30.6 \% \\
\text { Less than high school }=8.5 \%\end{array}$ \\
\hline Household income & 1,361 & $\begin{array}{l}\text { Greater than } \$ 75,000=40.9 \% \\
>\$ 40,000 \text { and }<\$ 75,000=32.7 \% \\
\text { Less than } \$ 40,000=26.4 \%\end{array}$ \\
\hline Political identification & 1,354 & $\begin{array}{l}\text { Independent }=36.0 \% \\
\text { Democrat }=34.2 \% \\
\text { Republican }=27.1 \% \\
\text { Other }=2.7 \% \\
\text { Conservative scale } \\
\text { Range }=0 \text { 'weak'-100 'very strong' } \\
\text { Mean }=47.4\end{array}$ \\
\hline Prior crime victim & 1,361 & $\begin{array}{l}\text { Household never victimized }=50.1 \% \\
\text { Household victimized at least once }=49.9 \%\end{array}$ \\
\hline
\end{tabular}

Prior Dispositions of Respondents

The questionnaire included several sets of questions to measure variables of interest that could not be directly observed, known as "latent variables" (Long 1983). These variables were included as controls in the analysis below. Seven latent variables were constructed by analyzing the covariance of the responses collected from these sets of questions. The questions were designed to capture prior dispositions of respondents and included items that measured the constructs presented below. Unless otherwise noted, the observed variables were four-point Likert scales (for example: agree strongly; agree; disagree; disagree strongly). We used the Cronbach's Alpha statistic to measure the internal consistency of the observed variables that comprised the latent variables (Cronbach 1951). Alpha varies from zero to one with higher values indicating a greater degree of reliability in measurement. As will be shown below, all the latent variables had Cronbach's Alpha statistics that equaled or exceeded .75, suggesting good internal consistency across the observed variables that comprised the latent variables. The confirmatory factor analysis loadings for the endogenous variables that comprise our latent variables are provided in the results section. All endogenous variables loaded very highly on their respective factors. 


\section{Identification with the police}

Psychological research has shown that individuals who identify with and feel connected to particular groups are more likely to view members of this group more positively and members of other groups more negatively (e.g. Gaertner et al. 1989). Five questions on a respondent's identification with police were included (alpha $=.85$ ). Respondents were asked to agree-disagree that: "If you talked to most of the police officers who work in your neighborhood, you think you would find they have similar views to your own on many issues"; "You can usually understand why the police who work in your neighborhood are acting as they are in a particular situation"; "You generally like the police officers who work in your neighborhood"; "If most of the police officers who work in your neighborhood knew you they would respect your values"; and "Most of the police officers who work in your neighborhood would value what you contribute to your neighborhood".

\section{General Political Ideology}

Relative to those with liberal political views, individuals with conservative views are more likely to hold positive opinions of law enforcement and the police (Tyler et al. 1997). Four questions on respondents' general political ideology were included (alpha $=.82$ ): "Where would you place yourself on a scale of political views from extremely liberal to extremely conservative?"; "Generally speaking, do you think of yourself as a strong democrat to a strong republican?"; and "Can you tell me your feelings about liberals and conservatives using a thermometer scale ranging from 0 to 100 reflecting cold to hot (50 is no feelings)?"

\section{Trust in Government Intervention}

Research has found that individuals who trust in the U.S. government were more likely to obey laws and show willingness to defer to authorities (Tyler and Mitchell 1994; Tyler and Huo 2002). Three questions measuring an individual's confidence in U.S. government intervention were included $($ alpha $=.83$ ). Respondents were asked to agree-disagree that: "Some people think that the government in Washington should do everything possible to improve the standard of living for all Americans."; "Some people think that the government in Washington is trying to do too many things that should be left to individuals and private businesses"; and "Some people think that racial minorities in the US have been discriminated against for so long that the government has a special obligation to help improve their living standards."

\section{Evaluations of Police Effectiveness}

Citizens who view the police as doing a poor job in dealing with crime express less satisfaction with the police and lower confidence in the police (Weitzer and Tuch 2006). Three questions on police effectiveness were included (alpha $=.84$ ). Respondents were asked: "How effective are the police in fighting crime in your neighborhood?" (measured "very effective" to "not effective at all"); "When people in your neighborhood call the police to ask for help how quickly do the police respond" (measured "very quickly" to "no response at all"); and "How effective are the police in your neighborhood at helping people who ask them for help?" (measured "very effective" to "not effective at all"). 


\section{Fear of Crime}

Feelings of personal safety influence citizens' approval of the police (Weitzer and Tuch 2006). When citizens are fearful o being a crime victim, their satisfaction with the police decreases. Three questions on respondents' fear of crime were included (alpha $=.75$ ). Respondents were asked: "How worried are you about being a crime victim?"; "How worried are you about your home being broken into?"; and "How worried are you about being robbed, assaulted or mugged in your neighborhood?" For these three questions, response items included "a great deal," "somewhat," "a little," and "not much at all."

\section{Concerns About Neighborhood Disorder}

Fear of crime has been found to be correlated with social and physical disorder in neighborhoods (Skogan 1990). Five questions on respondents' concerns with disorder in their neighborhoods were included $($ alpha $=.87)$. Respondents were asked: "How often do you see these conditions in your neighborhood?": "Empty beer bottles on the streets or sidewalks"; "Graffiti on the walls"; "Gangs hanging out on the streets"; "People drinking beer, wine or liquor on the street"; and "People buying or selling drugs on the street". For these five questions, response items included "usually," "sometimes," "rarely," and "almost never."

\section{Personal Experience with the Police}

Police treatment of citizens during an encounter affects citizens' views of the police more strongly than the outcome of the encounter (i.e. problem resolution, citation, or an arrest). When police treat citizens unfairly, brusquely, or discourteously, the experience has a negative influence not only on their assessments of the immediate encounter but also of their overall opinions of the police (Tyler 2006; Reisig and Chandek 2001). Some 66.8 percent of the 1,361 respondents reported a prior encounter with the police involving a crime or some possible violation of the law such as a driving infraction. For those who had at least one previous encounter with the police, the following six procedural justice questions were asked on their most recent interaction (alpha $=.93$ ): "I had the opportunity to describe my situation before decisions were made"; "I was treated the same way that others would be treated in a similar situation"; "The police made their decisions based upon facts"; "The police cared about my concerns"; "The police treated me politely"; and "the police respected my rights".

\section{Manipulated Social Contextual Variables}

Citizen experiences with police and other domains of criminal law take place within a larger social and political context of police-community relations. Incidents such as the Rodney King beating in Los Angeles, or the shooting of Amadou Diallo or Sean Bell in New York, or riots in Cincinnati against perceived police abuses may have framing effects on the ways that citizens perceive, interpret and evaluate police actions. Information on problematic past behavior of individuals involved in police actions, such as the past use of racial epithets by Detective Mark Fuhrman in the O.J. Simpson murder trial or whether the citizen in the interaction is a previously convicted felon, may similarly influence how citizens appraise police behavior. Knowledge of whether the initial stop was lawfully conducted by officers may also impact how citizens assess subsequent police behaviors during the same incident. Accordingly, we also suspect that these framing events influence not only how citizens perceive and evaluate police-citizen interactions, but they also moderate the salience of 
individual and general experiences of citizens in their influence on the evaluation of the legitimacy of police actions. We hypothesized that alternate descriptions of social contextual factors would influence our respondents' appraisals of police behavior.

Prior to viewing a video, respondents were given background information about the social context of that video. That information addressed four issues: the climate of police-community relations in the city, context of the stop, officer history, and citizen history. In each contextual variation, there were three framing conditions: negative, neutral, and positive. Respondents were randomly allocated these three framing conditions for each of the four issues resulting in 81 different possible combinations $\left(3^{4}=81\right.$ groups of subjects in the factorial experiment).

\section{City Climate of Police-Community Relations}

Respondents were told that the police department had been cited for its strong community policing work, had received extensive negative media coverage for poor community relations and civil rights violations, or no information was provided.

\section{Stop Context}

The stop context was described as legal, characterized as illegal, or neutral information was provided.

\section{Officer History}

The officer(s) in the videos had either been recommended for a commendation recognizing high quality and integrity in their work, had been recommended for in-service training to address inconsistent decision making in enforcing the law, or no information was provided.

\section{Citizen History}

The citizen(s) in the videos were presented as having a prior criminal record, not having a prior criminal record, or no information was provided.

Polychotomous dummy variables were constructed to represent the framing conditions for each social context issue. Using "police history" as an example, we created two dummy variables to represent negative $(0=$ not negative, $1=$ negative $)$ and neutral $(0=$ not neutral, $1=$ neutral) descriptions of the police officer(s) in the videos; the positive description served as the reference category. To determine whether the randomization of respondents across the varying social context conditions was achieved, we used Ordinary Least Squares (OLS) and Logistic regression models to analyze whether there were any statistically-significant differences in the basic socio-demographics of the respondents in each grouping. In this exploratory exercise, the framing effects dummy variables were used as predictors of age, race, sex, income, education, prior crime victimization, and political orientation in the respondents. ${ }^{6}$ Stata 12.0 statistical software was used to execute all statistical models (StataCorp 2011).

\footnotetext{
${ }^{6}$ OLS regressions were used to analyze the normally-distributed interval-level dependent variables "age" and "conservative" scale. Logistic regression models were used to examine the remaining dichotomous dependent variables: "White" $(0=$ non-white, $1=$ white $)$, "male" $(0=$ female, $1=$ male $)$, "income $>\$ 40 \mathrm{~K} "$ $(0=$ household income $\leq \$ 40,000$ per year, $1=$ household income $>\$ 40,000$ per year $)$, "college + " $(0=$ less education than a bachelor's degree, $1=$ bachelor's degree or higher $)$, and "victim" $(0=$ household member was a prior victim of crime, $1=$ household member was not a prior victim of crime).
} 
The results of OLS and Logistic regression models that tested the randomization procedure used by KN to allocate respondents among the three framing conditions for the four social context issues are available in "Appendix" Table 5. Briefly, there were very few statistically-significant $(p<.05)$ differences in the age, race, sex, income, education, prior crime victimization, and political orientation in the respondents who were allocated to the three framing conditions for the four social context issues. Randomization sometimes results in a small number of stochastic differences in group characteristics (Rossi et al. 2004). This suggests that the manipulated social contextual conditions were successfully randomized across the 1,361 respondents in the study. ${ }^{7}$

\section{Videos Shown to Respondents and Outcome Variable}

Respondents viewed three videos, presented in random order. ${ }^{8}$ The videos were chosen to vary the nature of the interaction between the police officer and the citizen. However, it is important to note here that this study was not designed to identify a representative sample of videos drawn from a population of police-citizen interactions so predictions could be made about how specific kinds of interactions may modify the impact of contextual characteristics on subject perceptions. The research was simply designed to determine whether varying social contextual factors affected citizen perceptions of observed policecitizen interactions and whether any identified effects were consistent across varied scenarios. In the first video the officers used a higher level of force/conflict than did the citizen, who was rude. In the second video, the level of force/conflict was high on both sides. In the third video, the level of force/conflict was low on both sides. Videos 2 and 3 involved interactions between white police officers and African-American citizens.

\section{Video 1: Rude Citizen/Police Use Force}

This video involved a middle age white male who was pulled over by the police during a traffic stop. The citizen was rude toward the police, did not follow police instructions, and refused to produce identification. The police officer, a middle-aged white male, responded to the belligerent citizen by applying force to restrain and arrest him.

\section{Video 2: Aggressive Citizen/Police Actively Use Force}

This video showed two white police officers responding to a conflict in a parking lot. The citizen, an African-American male, was aggressive in physically pushing the police officers who then responded by use of force and ended up trying to handcuff the civilian.

\footnotetext{
7 Table 2 identifies only 6 statistically-significant $(p<.05)$ differences across 168 hypothesis tests $(3$ videos $* 8$ contextual dummy variables per video $* 7$ outcome variables). This is lower than the 8.4 statistically-significant results that would be expected by chance alone for 168 hypothesis tests at a .05 level of statistical significance. We also ran similar OLS and Probit regression models for all observed variables that comprised the latent variables described above; these analyses yielded similar results that supported successful randomization. Further, we created an 81 cell variable representing the different combinations of framing conditions and social contextual issues and ran a series of Chi square tests to examine whether the observed distributions of cell counts were significantly different from the expected distribution of cells counts. We did not find any statistically significant differences between the observed and expected distributions, suggesting successful randomization by this measure.

8 These videos showed real-life interactions between police officers and citizens. We acquired the three study videos from the internet and edited the footage down to $30 \mathrm{~s}$ that captured the key events briefly described in this section.
} 


\section{Video 3: Confused Citizen/Directive Police}

In this video, two white police officers conducted a pedestrian stop of a young AfricanAmerican male. The citizen was polite toward the police and confused about the situation. The officers were acquiescent and the citizen complied with police requests.

\section{Outcome Variable: The Police were Wrong/Should be Punished}

The respondents were asked six questions after viewing each of the three videos. As with the other observed variables, these questions were framed as four-point Likert scales (agree strongly; agree; disagree; disagree strongly). The questions were: "The police violated the law"; "The police engaged in misconduct"; "The police were reasonable and fair" (reverse scored); "The officers should be punished"; "The officers should not patrol the streets"; and "The person should sue the police" (video 1 alpha $=.95$, video 2 alpha $=.95$, video 3 alpha $=.94)$.

\section{Analytical Strategy}

The data were analyzed using structural equation modeling (SEM) routines. SEMs are well-known social science methods that can encompass a broad range of statistical models including linear regression, measurement models, and simultaneous equations (Bollen 1989; Gau 2010). This approach is very attractive to social science analysts due to its generality and flexibility. SEMs allow the consideration of simultaneous equations with multiple endogenous variables, permit measurement error in exogenous and endogenous variables, allow multiple indicators of latent constructs, permit more general measurement models than traditional factor-analytic structures, and enable the researcher to specify structural relationships among the latent variables (Bollen 1989; Bollen and Long 1993). In essence, this flexibility facilitates the comparison of the theoretical model built by the analyst to the observed patterns of covariance within the data (Kline 2010). Comparing theorized relationships to observed relationships forms the basis for model evaluation and for reaching substantive conclusions from SEM analyses.

Most applications of SEMs are characterized by the following four steps: (1) model specification, formulated based on theory and past research in the area; (2) model identification, where the researcher determines whether it is possible to find unique values for the parameters of the specified model; (3) model estimation, determined by the distributional properties of the variables being analyzed; and (4) testing model fit, after estimates are obtained the researcher can determine whether the model fits the data (Bollen and Long 1993). SEM programs translate the user-generated model into a series of covariance matrices which is compared with data-generated matrices to determine the extent of the match or fit (Kline 2010). The SEM software includes measurement output, which presents and assesses the relationships between the endogenous variables and the latent variables, and structural output, which presents and assesses the relationships between the exogenous independent variables and the dependent variable. A fifth step, model re-specification, is added if the model doesn't fit the data adequately. When the model is re-specified, the four primary steps are repeated (sometimes multiple times, see Bollen 1989). After some respecification to ensure that the latent variables (and the endogenous variables that comprised them) and other predictor variables best fit the data, we developed SEMs to analyze 
the effects of the manipulated social contextual factor variables on respondents' reactions to the three police-citizen interaction videos. ${ }^{9}$

The factor loadings for the endogenous variables that comprised the independent and dependent latent variables in the SEMs for the three videos are available in "Appendix" Table $6 .^{10}$ These maximum likelihood estimates represented the measurement portions of the SEMs. As can be observed, all factor loadings were consistently high, suggesting very strong correlations between the endogenous variables and the underlying latent variables measured (Kim and Mueller 1978).

\section{Results}

\section{Main Effects Models: Manipulated Social Contextual Variables Only}

Table 2 presents the results of the SEMs analyzing the effects of the manipulated social contextual variables on the dependent latent variable measuring the extent to which the respondents believed the police were wrong and should be punished, excluding the other control variables. ${ }^{11}$ Table 2 also reports the results of three goodness-of-fit metrics: the Comparative Fit Index (CFI), the Root Mean Square Error of Approximation (RMSEA), and the Standardized Root Mean Residual (SRMR). CFI values larger than .90 and RMSEA and SRMR values below .05 suggest very good fit between the hypothesized models and the true covariance matrices underlying the data (see Gau 2010). ${ }^{12}$ Indeed, by these standards, our three main effects models fit the observed data very well.

\footnotetext{
9 We also recognized that our main effects models could be structured as hierarchical linear models to analyze multiple observations nested within a single subject. This analysis required restructuring the study dataset into a longitudinal panel design where each respondent views three consecutive videos for a total of 4,083 observations ( 3 videos * 1,361 respondents). In Stata 12.0, we used the XTSET command to declare that the data were structured in the longitudinal panel format and the XTREG command to execute hierarchical linear models to analyze the data. Video dummy variables and manipulated social context dummy variables were used to measure the main effects of viewing the different police-citizen interaction videos and the randomly-allocated framing effects, respectively. Interactive dummy variables were constructed (video dummies * manipulated social context dummies) and entered into the model to determine whether the observed framing effects were consistent across the three videos. These results were congruent with the main effects findings presented here and are available upon request from the authors.

${ }^{10}$ Since they are not directly measured, latent variables do not have intrinsic variances. For the factor loadings in Table 3, the variances of the latent variables were constrained to equal " 1 " for ease of interpretation (StataCorp 2011, p. 254). These coefficients can be interpreted as correlations that range from "0" to " 1 ".

11 Unfortunately, small numbers of the 1,361 respondents did not answer all of the study questions for each video viewed and for the questionnaire. We handled missing responses through listwise case deletions. As Table 2 presents, the number of respondents included in our analyses ranged from 1,232 (90.5\% of 1,361) to $1,246(91.5 \%)$. We used $t$-tests to examine whether there were any statistically-significant differences between included and excluded cases for the covariates used in the SEM analyses presented in Tables 2, 3 and 4. Our simple comparisons did not reveal any statistically-significant differences between the missing cases and the included cases. This suggests that the data were missing at random and, as such, listwise case deletions were an appropriate method to address the very modest missing data problem.

12 The CFI assesses the fit of a user-specified solution in relation to a more restricted, nested baseline model in which the covariances among all input indicators are fixed to zero or no relationship among variables is posited (Brown 2006, p. 84). The CFI coefficient value ranges from 0 to 1.00 with values greater than 0.90 indicating a reasonably good fit of the hypothesized model (Hu and Bentler 1999). RMSEA takes the error of population approximation and degrees of freedom into account and measures the lack of fit of the hypothesized model to the population covariance matrix. SRMR is estimated in a similar to RMSEA but does not penalize model complexity. As a general rule of thumb, SRMR and RMSEA results of 0.05 or less indicates a close approximate fit of the model (Hu and Bentler 1999).
} 
Table 2 Structural equation models for three police-citizen interaction videos without control variables

\begin{tabular}{|c|c|c|c|}
\hline Variables & $\begin{array}{l}\text { Video } 1 \\
b \text { (SE) }\end{array}$ & $\begin{array}{l}\text { Video } 2 \\
b \text { (SE) }\end{array}$ & $\begin{array}{l}\text { Video } 3 \\
b \text { (SE) }\end{array}$ \\
\hline City neutral & $-.042(.032)$ & $-.021(.033)$ & $-.028(.033)$ \\
\hline City negative & $-.085(.032)^{*}$ & $-.104(.032)^{*}$ & $-.118(.033)^{*}$ \\
\hline Stop context neutral & $-.142(.032)^{*}$ & $.024(.033)$ & $-.019(.033)$ \\
\hline Stop context illegal & $-.202(.032)^{*}$ & $-.084(.033)^{*}$ & $-.130(.033)^{*}$ \\
\hline Officer neutral & $-.048(.032)$ & $-.051(.033)^{*}$ & $.006(.033)$ \\
\hline Officer negative & $-.165(.032)^{*}$ & $-.065(.030)^{*}$ & $-.099(.033)^{*}$ \\
\hline Citizen neutral & $.042(.032)$ & $-.010(.033)$ & $.068(.030)^{*}$ \\
\hline Citizen negative & $.079(.032)^{*}$ & $.019(.033)$ & $.094(.033)^{*}$ \\
\hline $\mathrm{N}$ & 1,246 & 1,238 & 1,232 \\
\hline Log likelihood & $-47,802.689$ & $-48,820.074$ & $-49,232.808$ \\
\hline \multicolumn{4}{|l|}{ Likelihood ratio test } \\
\hline Chi square & $1,623.11$ & $1,653.09$ & $1,601.50$ \\
\hline Degrees of freedom & 538 & 538 & 538 \\
\hline$p>$ Chi square & .000 & .000 & .000 \\
\hline CFI & .955 & .950 & .951 \\
\hline RMSEA & .043 & .041 & .040 \\
\hline SRMR & .046 & .057 & .056 \\
\hline
\end{tabular}

For all framing effects dummy variables, positive descriptions served as the reference categories. Dependent variable is the "police were wrong/police should be punished" latent variable

$S E$ standard error

$* p<.05$

As Table 2 reveals, the social contextual framing effects dummy variables were associated with statistically-significant impacts on respondent assessments of police actions in all three videos. When compared to a positive description of the climate of police-community relations in the city, a negative description was associated with a statistically-significant negative effect on respondent ratings of police actions $(p<.05)$ in Video 1 (rude citizen, police use force), Video 2 (aggressive citizen, police use force), and Video 3 (confused citizen, directive police). These relationships suggest that the context of existing police-community relations in a given city has a noteworthy impact on how individuals assess the appropriateness of police actions across a variety of police-citizen interaction scenarios.

Relative to a legal police stop descriptions, illegal stop descriptions were associated with statistically-significant negative impacts on respondent ratings of police actions $(p<.05)$ for all three videos. When respondents viewed Video 1(rude citizen, police use force), a neutral stop description was also associated with a statistically-significant negative effect on respondent assessment of police behavior relative to a legal stop description $(p<.05)$. Clearly, the legality of the stops that initiated police-citizen interactions exerted a powerful influence on respondent evaluations of police actions in those interactions.

When compared to a positive description of the police officer's prior history, a negative description was associated with a statistically-significant negative impact on respondent ratings of police actions $(p<.05)$ in Video 1 (rude citizen, police use force), Video 2 (aggressive citizen, police use force), and Video 3 (confused citizen, directive police). Conversely, relative to a positive description of the citizen's prior history, a negative description was associated with a statistically-significant positive impact on respondent 
ratings of police actions $(p<.05)$ in Video 1 and 3. Relative to a positive citizen history description, a negative description was not associated with a significant effect on respondent ratings of police actions in Video 2 (aggressive citizen, police use force). It is important to remember, however, that the citizen in this video immediately attacked the responding officers. This obviously criminal behavior probably offset any beneficial effects of a positive description of the citizen's prior history on respondent assessments of police actions in the video.

\section{Main Effects Models: Manipulated Social Contextual Variables with Control Variables}

Table 3 presents the maximum likelihood estimates for the effects of the exogenous latent variables and two sets of control variables on the dependent latent variable measuring the extent to which the respondents believed the police were wrong and should be punished for Video 1. The size, direction, and statistical significance of the coefficients for the manipulated social contextual variables were very similar in Table 2 . The addition of a series of control variables did not substantively change our findings that social contextual frames matter in individual assessments of police behavior. The three goodness-of-fit indices reported in both tables confirmed that the hypothesized models fit the observed data very well.

The second column in Table 3 provides the estimates with demographic controls for Video 1. Table 4 presents the analogous estimates for Videos 2 and 3. Estimates for all three videos are quite similar. In Table 3, age, sex, race covariates were not associated with statistically-significant effects on the respondents' judgments of whether the police officers in the three videos were wrong and should be punished. Nonetheless, the non-statistically-significant relationships were in the expected direction with older, whites, males ${ }^{13}$ having more positive assessments of police officer actions (Weitzer and Tuch 2006). The insignificant race effect was certainly surprising, but was most likely due to the small number of African-Americans in the sample (only $14 \%$ of the respondents). However, respondents with bachelor's degrees or higher levels of education were consistently associated with more negative assessments of the actions of the police officers $(p<.05)$. Holding other predictors constant, better educated respondents were associated with more critical judgments of police actions relative to their less educated counterparts. Conversely, respondents with incomes over $\$ 40$ thousand had more positive attitudes toward police $(\mathrm{p}<.05)$, indicating the complicated effects of socioeconomic status as measured by education and income on attitudes toward the police.

Column 3 reports model estimates with a variety of different control variables entered into the model. The effects of the framing variables are little changed. Relative to respondents who did not experience a household victimization, respondents from households that did experience a prior victimization were associated with more positive ratings of police officer actions $(p<.05)$ in Video 2 (aggressive citizen, police use force). However, controlling for other covariates, there were not any statistically-significant differences in the assessments of police actions made by respondents from households that did and did not experience prior victimizations in the other videos.

Controlling for the other covariates, the latent variables capturing the respondents' trust in government, beliefs on police effectiveness, concerns about neighborhood disorder, and fear of crime were not associated with any statistically-significant influences on their assessments of police actions in the three videos. Subjects who identified with police officers were more likely to appraise their actions more positively. As respondents'

13 The sex effects were statistically significant in Videos 2 and 3 and in the expected direction with males expressing more favorable attitudes toward police. 
Table 3 Structural equation models for police-citizen interaction video 1

\begin{tabular}{|c|c|c|c|}
\hline Variables & $\begin{array}{l}\text { Equation } 1 \\
b \text { (SE) }\end{array}$ & $\begin{array}{l}\text { Equation } 2 \\
b \text { (SE) }\end{array}$ & $\begin{array}{l}\text { Equation } 3 \\
b \text { (SE) }\end{array}$ \\
\hline City neutral & $-.042(.032)$ & $-.039(.032)$ & $-.036(.030)$ \\
\hline City negative & $-.085(.032)^{*}$ & $-.085(.032)^{*}$ & $-.088(.031)^{*}$ \\
\hline Stop context neutral & $-.142(.032)^{*}$ & $-.139(.032)^{*}$ & $-.149(.031)^{*}$ \\
\hline Stop context illegal & $-.202(.032)^{*}$ & $-.211(.031)^{*}$ & $-.211(.030)^{*}$ \\
\hline Officer neutral & $-.048(.032)$ & $-.046(.032)^{*}$ & $-.054(.031)$ \\
\hline Officer negative & $-.165(.032)^{*}$ & $-.163(.031)^{*}$ & $-.161(.029)^{*}$ \\
\hline Citizen neutral & $.042(.032)$ & $.053(.032)$ & $.044(.030)$ \\
\hline Citizen negative & $.079(.032)^{*}$ & $.070(.032) *$ & $.074(.031)^{*}$ \\
\hline Age $>30$ & & $.034(.028)$ & $.032(.027)$ \\
\hline Male & & $.018(.028)$ & $.015(.028)$ \\
\hline White & & $.039(.028)$ & $.020(.028)$ \\
\hline College+ & & $-.093(.028)^{*}$ & $-.061(.028)^{*}$ \\
\hline Income $>\$ 40 \mathrm{~K}$ & & $.072(.028)^{*}$ & $.049(.027)$ \\
\hline Prior victim & & & $.041(.028)$ \\
\hline Prior police encounter & & & $.026(.027)$ \\
\hline Prior encounter X PJ LV & & & $-.077(.032)^{*}$ \\
\hline Police identification LV & & & $-.229(.045)^{*}$ \\
\hline Political ideology LV & & & $.127(.048)^{*}$ \\
\hline Trust in government LV & & & $-.017(.048)$ \\
\hline Police effectiveness LV & & & $.010(.051)$ \\
\hline Neighborhood disorder LV & & & $-.034(.042)$ \\
\hline Neighborhood fear LV & & & $-.062(.041)$ \\
\hline $\mathrm{N}$ & 1,246 & 1,229 & 1,229 \\
\hline Log likelihood & $-47,802.689$ & $-51,476.01$ & $-54,264.752$ \\
\hline \multicolumn{4}{|l|}{ Likelihood ratio test } \\
\hline Chi square & $1,623.11$ & $1,782.695$ & $1,779.41$ \\
\hline Degrees of freedom & 538 & 648 & 708 \\
\hline$p>$ Chi square & .000 & .000 & .000 \\
\hline CFI & .955 & .950 & .954 \\
\hline RMSEA & .043 & .038 & .035 \\
\hline SRMR & .046 & .042 & .026 \\
\hline
\end{tabular}

For all framing effects dummy variables, positive descriptions served as the reference categories. Dependent variable is the "police were wrong/police should be punished" latent variable

$P J$ procedural justice, $L V$ latent variable, $S E$ standard error

$* p<.05$

identification with police decreased (moving from "strongly agree" towards "strongly disagree"), their assessments of police actions were more negative $(p<.05)$ holding the other predictors constant. Subjects who embraced a more conservative political ideology and its typically stronger "law and order" orientation viewed police actions in a more positive light. Controlling for the other covariates, as respondents described themselves as more conservative in their political ideology, their assessments of police actions in all three videos became increasingly more positive $(p<.05)$. 
Table 4 Full structural equation models for three police-citizen interaction videos

\begin{tabular}{|c|c|c|c|}
\hline Variables & $\begin{array}{l}\text { Video } 1 \\
b \text { (SE) }\end{array}$ & $\begin{array}{l}\text { Video } 2 \\
b \text { (SE) }\end{array}$ & $\begin{array}{l}\text { Video } 3 \\
b \text { (SE) }\end{array}$ \\
\hline Age $>30$ & $.032(.027)$ & $.039(.026)$ & $.003(.027)$ \\
\hline Male & $.015(.028)$ & $.159(.026)^{*}$ & $.076(.028)^{*}$ \\
\hline White & $.020(.028)$ & $.030(.028)$ & $.028(.029)$ \\
\hline College + & $-.061(.028)^{*}$ & $-.083(.027)^{*}$ & $-.068(.028)^{*}$ \\
\hline Income $>\$ 40 \mathrm{~K}$ & $.049(.027)$ & $.047(.027)$ & $.032(.028)$ \\
\hline Prior victim & $.041(.028)$ & $.067(.028) *$ & $.049(.029)$ \\
\hline Prior police encounter & $.026(.027)$ & $.019(.027)$ & $-.017(.028)$ \\
\hline Prior encounter X PJ LV & $-.077(.032)^{*}$ & $-.035(.032)$ & $-.091(.033)^{*}$ \\
\hline Police identification LV & $-.229(.045)^{*}$ & $-.213(.045)^{*}$ & $-.206(.046)^{*}$ \\
\hline Political ideology LV & $.127(.048)^{*}$ & $.104(.048)^{*}$ & $.180(.049)^{*}$ \\
\hline Trust in government LV & $-.017(.048)$ & $.062(.048)$ & $-.008(.050)$ \\
\hline Police effectiveness LV & $.010(.051)$ & $-.037(.051)$ & $.094(.052)$ \\
\hline Neighborhood disorder LV & $-.034(.042)$ & $-.042(.036)$ & $.076(.041)$ \\
\hline Neighborhood fear LV & $-.062(.041)$ & $-.054(.047)$ & $.059(.040)$ \\
\hline City neutral & $-.036(.030)$ & $-.006(.030)$ & $-.024(.031)$ \\
\hline City negative & $-.088(.031)^{*}$ & $-.072(.030)^{*}$ & $-.123(.030)^{*}$ \\
\hline Stop context neutral & $-.149(.031)^{*}$ & $.035(.031)$ & $-.037(.031)$ \\
\hline Stop context illegal & $-.211(.030)^{*}$ & $-.085(.030)^{*}$ & $-.129(.030)^{*}$ \\
\hline Officer neutral & $-.054(.031)$ & $-.066(.030)^{*}$ & $.005(.031)$ \\
\hline Officer negative & $-.161(.029)^{*}$ & $-.068(.030)^{*}$ & $-.099(.031)^{*}$ \\
\hline Citizen neutral & $.044(.030)$ & $.014(.030)$ & $.071(.030)^{*}$ \\
\hline Citizen negative & $.074(.031)^{*}$ & $.038(.030)$ & $.087(.030)^{*}$ \\
\hline $\mathrm{N}$ & 1,229 & 1,240 & 1,232 \\
\hline Log likelihood & $-54,264.752$ & $-51,914.123$ & $-55,422.515$ \\
\hline \multicolumn{4}{|l|}{ Likelihood ratio test } \\
\hline Chi square & $1,779.41$ & $1,712.49$ & $1,941.26$ \\
\hline Degrees of freedom & 708 & 708 & 708 \\
\hline$p>$ Chi square & .000 & .000 & .000 \\
\hline CFI & .954 & .949 & .946 \\
\hline RMSEA & .035 & .038 & .038 \\
\hline SRMR & .026 & .026 & .027 \\
\hline
\end{tabular}

For all framing effects dummy variables, positive descriptions served as the reference categories. Dependent variable is the "police were wrong/police should be punished" latent variable

$P J$ procedural justice, $L V$ latent variable, $S E$ standard error

$* p<.05$

Holding the other variables constant, having a prior encounter with the police or not was not associated with any statistically-significant differences in respondent assessments of police actions. However, for those who did have a prior encounter, the nature of their experiences with the police in their most recent interaction associated with a statisticallysignificant effect $(p<.05)$ on their assessments of police actions. As these respondents perceived their prior interaction with the police to be increasingly less procedurally just 
(moving from "strongly agree" towards "strongly disagree"), their assessments of police behavior became increasingly negative.

An important aspect of column 2 Table 3 is that it allows us to compare the size of our social context variables with the effect of different demographic variables. Specifically, we focus on education because its effect is the largest and its substantive importance. An individual's level of educational attainment is regarded as a very important predictor of a variety of life outcomes and behaviors such as social status (Beeghley 2004), voting (Wolfinger and Rosenstone 1980), and criminal activity (Gottfredson 1981). Indeed, in this analysis, the only control variable that produced a consistent effect across all three videos was the level of education of the respondent. In Table 3, column 2, the reported effect size for having some or more college is -.093 with a standard error of $.028 .^{14}$

The manipulated social contextual variables yield effect sizes that are similar, and sometimes larger in size than the effects of educational attainment on individual appraisals of police behavior. Describing the city in negative as opposed to positive terms prior to seeing a video has a -.085 effect on a respondent's evaluation of police behavior. Describing the circumstances of the stop in the video in either neutral (-.139) or as illegal $(-.211)$ have larger negative effects than that of education. A negative descriptive of the police officer also leads to a much larger effect $(-.163)$. Describing the citizen in negative terms leads to a somewhat smaller effect (.070) than education.

\section{Conclusion}

The results of our randomized factorial experiment suggest that the immediate priors a person has about a situation can have a considerable effect on their evaluation of that situation, with effects as large as or even larger than a key demographic variable such as education. As such, what these results show is that the perspective a person brings to evaluating a situation can have a substantial effect independent of what actually occurred in that situation. This is an important insight in considering how citizens are likely to evaluate police behavior. Even in situations where police do act properly, citizens, because of their prior perspectives, may well evaluate police as not having done so. In many ways, our findings are consistent with research on the reliability of eyewitness testimony that suggests individual memories and perceptions can be manipulated, altered, and biased (Loftus et al. 2008). Beyond the objective events observed, eyewitness accounts can be notably influenced by prior attitudes and values held by individual observers (Wells and Olson 2003).

Consistent with cognitive and social psychology research on priming effects, social contextual factors shape citizen evaluations of police wrongdoing even when people see the same event. Depending on the content of the social context primes, people can react differently to an identical stimulus (Fiske and Taylor 1991; Balcetis and Lassiter 2010).

\footnotetext{
14 Arguably the effect of Education should be estimated without controlling for income, since presumably part of the effect of Education is mediated through Income. Dropping Income as a control only results in the effect of Education being reduced-with the effect dropping to -0.78 ( $\mathrm{SE}=.028, p<.05)$. In our sample, levels of Education are very modestly correlated with levels of Income $(r=.28)$. In reduced regression models of the effects of Education and Income on respondent assessment of police behavior, we find that both are statistically significant predictors of the outcome variable in all three videos. Controlling for Income, increasing levels of Education are associated with more negative perceptions of observed police behavior. This suggests that more educated people are more critical appraisers of police behavior independent of how much money they earn. Clearly, future research in this area should seek to better disentangle these complicated effects.
} 
Psychological research on consumer preferences suggests that priming a particular attribute increases the likelihood that this attribute will be used to interpret product information in an advertisement, and thus influences the evaluation of the advertised brand (Gardner 1983; Herr 1989). For the police, the activation of positive or negative attributions of observed police actions can stimulate or hinder citizen cooperation in resolving particular incidents or assistance in control of crime and disorder problems. Coupled with the existing research on procedural justice and police-community relations (Mazerolle et al. 2013; Reisig et al. 2007; Tyler 2003), the implications of these findings for the delivery of police services may be profound. While concentrated social disadvantage, racism, and isolation from political power are underlying causes, urban riots are usually sparked by negative perceptions of observed police behavior in a climate of persistently poor police-community relations (Skolnick and Fyfe 1993; U.S. National Advisory Commission on Civil Disorder 1968).

Citizen perceptions of their interactions with the police are strongly shaped by preexisting opinions of the police (Brandl et al. 1994; Rosenbaum et al. 2005). Vicarious experiences also influence the way citizens interpret and evaluate their own encounters with the police (Brunson 2007; Gallagher et al. 2001; Hohl et al. 2010; Weitzer and Tuch 2006). These global, pre-existing views of the police influence citizen assessments of police behavior in specific interactions and also their general views of the police. Our research adds to this line of scientific inquiry by demonstrating that situation-specific perceptions held just prior to viewing police-citizen interactions have strong impacts on citizen perceptions of the rightfulness or wrongfulness of police behavior during those interactions. Broader social contextual factors, such as the climate of police-community relations in a particular city, and immediate contextual factors, such as the lawfulness of the stop and the work history of the officer making the stop, clearly matter in citizen appraisals of police behavior. For instance, an older, upper-middle-class, conservative white male may hold innately positive views of the police and, in general, he may be very willing to cooperate with police. Our findings suggest that his assessment of an observed police action would be negatively impacted by immediate a priori knowledge that the police department in his city is being investigated for persistent patterns of abusive behavior, the officer in the encounter is being investigated on corruption charges, and/or the stop that initiated the encounter was illegal. This an important refinement to the existing literature that has generally examined more static measures of preexisting views on the legitimacy of police behavior.

The results of our randomized factorial experiment provides some support to the perspective that police executives and organizations can positively influence citizen interpretations of police actions by striving to create a climate of positive police-community relationships in cities (Skogan and Frydl 2004; Skolnick and Fyfe 1993). In essence, the police can shape the social contexts that influence citizen perceptions of police activities on the street. Community policing programs, in particular, seem to be well positioned to improve citizen judgments of the appropriateness of police behavior in specific incidents. The available evaluation evidence suggests that community policing programs enhance police-community relationships and improve citizens' judgments of police actions (Skogan and Frydl 2004; Weisburd and Eck 2004). Our research suggests that these positive impressions of police departments and individual officers transfer to the interpretation of the rightfulness or wrongfulness of particular police actions made in specific interactions with citizens. As such, the police may be able to create a "reservoir of goodwill" with the community that can extend to citizen interpretations of enforcement work on the street that could negatively impact the willingness of community members to cooperate with the police.

Equally important, police executives and organizations need to ensure that officers are lawful in their interrogations, searches and seizures, and use of force (Fyfe 2002; Gould and Mastrofski 2001). Police lawlessness seriously undermines citizen confidence and trust in 
law enforcement agencies (Skogan and Meares 2004). Citizens expect the police to enforce laws fairly according to the laws and rules that circumscribe their enforcement powers. In this study, relative to positive conditions, respondents made negative appraisals of police actions in contexts where police departments were suggested to be known for civil rights violations and other unlawful actions, particular officers were suggested to be problematic in their police work, and the stops that initiated the police-citizen interaction were illegal.

Our research, like prior studies, suggests that public judgments about the legitimacy of the police are influenced by their assessments of the manner in which the police exercise their authority (Tyler 2004, 2006). Under experimental conditions, the procedural justice experienced by respondents in their most recent encounter with the police impacted their assessments of police actions in all three videos independent of the social contextual frames applied. Past experiences with police officers shaped citizen attributions of the legitimacy of those actors and the institutions they represent. When citizens have prior interactions where they believe the police treated them disrespectfully and unfairly, they negatively assess the actions of police officers in an independent subsequent event. Clearly, to improve citizen judgments of handling of specific incidents, police departments need to ensure that its officers are being procedurally just in their interactions with the public. As this research and prior research seems to indicate even if there is good relations between the community and their police force, a single negative encounter could overcome all the good faith effects (Brunson 2007; Gallagher et al. 2001; Hohl et al. 2010; Warren 2011; Weitzer and Tuch 2006).

This study, like most social science inquiries, has several limitations that future investigations could improve upon. Most importantly, there are very few young, non-white males in our study. It would be very important to determine the salience of social contextual factors for a population that is generally subjected to higher levels of police scrutiny and hold much more negative perceptions of the police (Brunson and Weitzer 2009; Weitzer and Tuch 2006). It is also important to remember the artificial context of the research study. While the use of videos of actual encounters is a significant improvement over written vignettes, respondents may have responded differently if they were physically present at the scene of the actual police-citizen interactions. Future scientific inquiries should also consider whether contextual factors shape procedural justice judgments of observed police-citizen interactions rather than limiting their assessments to perceptions of whether the police were wrong and should be punished. Indeed, there are a variety of refinements that future studies could make, such as including measures of global attitudes toward the police rather than limiting questions to police officers in the respondents' neighborhoods only and examining the role of violent household victimization rather than any household criminal victimization.

While complex and challenging, police executives and police organizations need to create positive social contextual environments in their jurisdictions by ensuring that "good policing" is uniformly applied to all neighborhoods. The ideas of legitimacy and procedural justice are central to this perspective. Police departments need to engage community policing principles, ensure that officers are lawful in their enforcement actions, and all citizens are treated in a fair and respectful manner. In return, police departments will accrue a variety of benefits such as improving their ability to control crime and hold offenders accountable and receiving more favorable interpretations of their enforcement actions on the street.

\section{Appendix}

See Tables 5 and 6. 


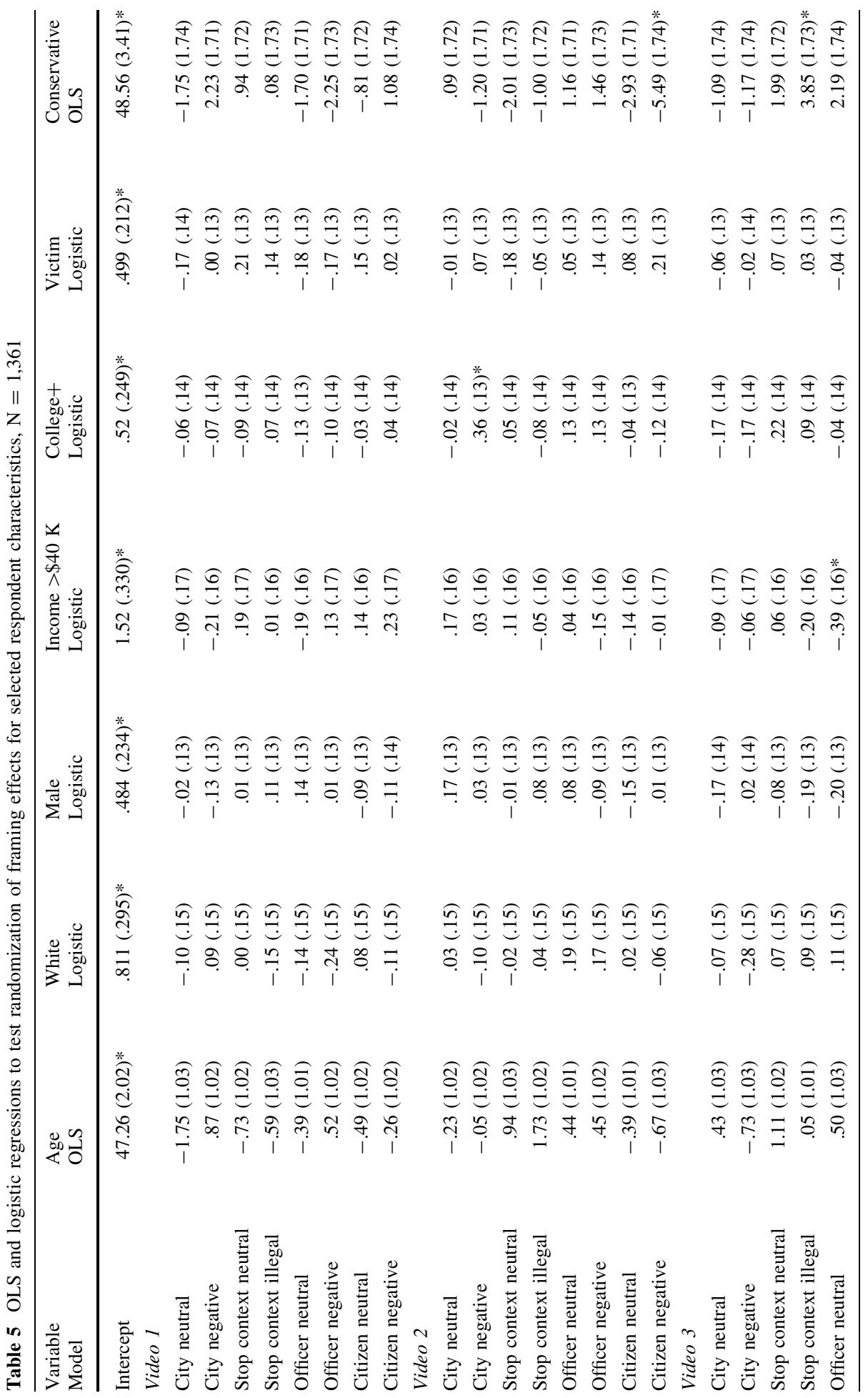




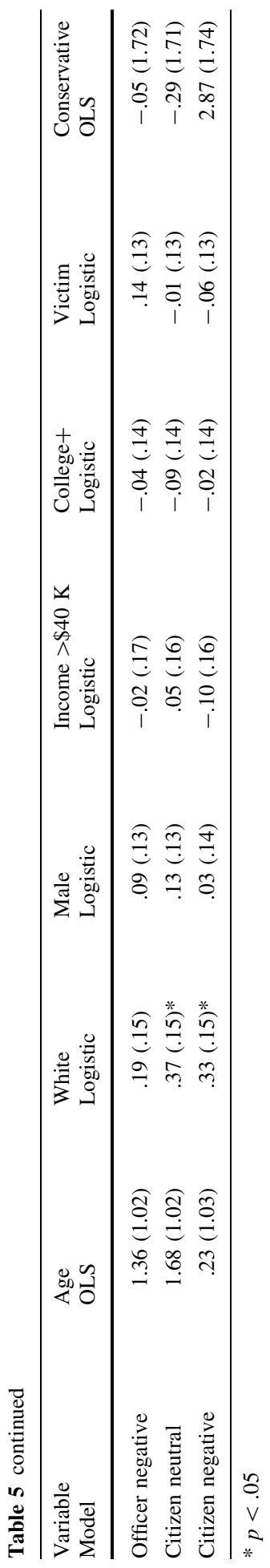


Table 6 Factor loadings for endogenous variables comprising latent variables in SEMs

\begin{tabular}{|c|c|c|c|}
\hline Latent variables & $\begin{array}{l}\text { Video } 1 \\
b \text { (SE) }\end{array}$ & $\begin{array}{l}\text { Video } 2 \\
b \text { (SE) }\end{array}$ & $\begin{array}{l}\text { Video } 3 \\
b \text { (SE) }\end{array}$ \\
\hline \multicolumn{4}{|l|}{ Identification w/police } \\
\hline Share similar views & $.716(.016)^{*}$ & $.724(.016)^{*}$ & $.718(.016)^{*}$ \\
\hline Understand police actions & $.722(.017)^{*}$ & $.708(.017)^{*}$ & $.707(.018)^{*}$ \\
\hline Like police in my area & $.784(.014)^{*}$ & $.786(.014)^{*}$ & $.781(.014)^{*}$ \\
\hline Respect my values & $.701(.018)^{*}$ & $.705(.018)^{*}$ & $.701(.018)^{*}$ \\
\hline Value my contributions & $.715(.017)^{*}$ & $.719(.017)^{*}$ & $.722(.017)^{*}$ \\
\hline \multicolumn{4}{|l|}{ Political ideology } \\
\hline Liberal versus conservative & $.891(.009)^{*}$ & $.890(.009)^{*}$ & $.889(.009)^{*}$ \\
\hline Democrat versus Republican & $.722(.015)^{*}$ & $.727(.015)^{*}$ & $.723(.015)^{*}$ \\
\hline Liberal scale (reverse) & $.828(.011)^{*}$ & $.827(.011)^{*}$ & $.831(.011)^{*}$ \\
\hline Conservative scale & $.747(.014)^{*}$ & $.749(.014)^{*}$ & $.746(.014)^{*}$ \\
\hline \multicolumn{4}{|l|}{ Trust in government } \\
\hline Improve living standards & $.842(.012)^{*}$ & $.841(.012)^{*}$ & $.839(.012)^{*}$ \\
\hline Gov't doing too much & $.847(.012)^{*}$ & $.842(.012)^{*}$ & $.841(.012)^{*}$ \\
\hline Should help minorities & $.711(.017)^{*}$ & $.720(.017)^{*}$ & $.714(.017)^{*}$ \\
\hline \multicolumn{4}{|l|}{ Police effectiveness } \\
\hline Reduce crime in my area & $.785(.014)^{*}$ & $.789(.014)^{*}$ & $.786(.014)^{*}$ \\
\hline Quick response to calls & $.769(.014)^{*}$ & $.767(.014)^{*}$ & $.766(.014)^{*}$ \\
\hline Help people when asked & $.860(.011)^{*}$ & $.856(.011)^{*}$ & $.859(.011)^{*}$ \\
\hline \multicolumn{4}{|l|}{ Neighborhood disorder concerns } \\
\hline Beer bottles on street & $.689(.017)^{*}$ & $.681(.017)^{*}$ & $.689(.017)^{*}$ \\
\hline Graffiti on walls & $.695(.016)^{*}$ & $.695(.017)^{*}$ & $.700(.017)^{*}$ \\
\hline Gangs on the streets & $.815(.012)^{*}$ & $.816(.012)^{*}$ & $.815(.012)^{*}$ \\
\hline Public drinking & $.803(.012)^{*}$ & $.800(.012)^{*}$ & $.801(.012)^{*}$ \\
\hline Drug selling & $.793(.013)^{*}$ & $.786(.013)^{*}$ & $.795(.013)^{*}$ \\
\hline \multicolumn{4}{|l|}{ Neighborhood fear of crime } \\
\hline Fear of victimization & $.745(.017)^{*}$ & $.743(.017)^{*}$ & $.743(.017)^{*}$ \\
\hline Home burglarized & $.861(.015)^{*}$ & $.858(.015)^{*}$ & $.858(.015)^{*}$ \\
\hline Street violence victim & $.620(.021)^{*}$ & $.621(.021)^{*}$ & $.613(.022)^{*}$ \\
\hline \multicolumn{4}{|l|}{ Procedural justice w/police } \\
\hline Described my situation & $.758(.016)^{*}$ & $.746(.017)^{*}$ & $.749(.017)^{*}$ \\
\hline Treated like others & $.732(.018)^{*}$ & $.732(.018)^{*}$ & $.731(.018)^{*}$ \\
\hline Police decision based on facts & $.839(.012)^{*}$ & $.840(.012)^{*}$ & $.839(.012)^{*}$ \\
\hline Police cared about concerns & $.853(.011)^{*}$ & $.857(.011)^{*}$ & $.854(.011)^{*}$ \\
\hline Treated me politely & $.895(.009)^{*}$ & $.889(.009)^{*}$ & $.894(.009)^{*}$ \\
\hline Respected my rights & $.898(.009)^{*}$ & $.892(.009)^{*}$ & $.899(.009)^{*}$ \\
\hline \multicolumn{4}{|l|}{ Police wrong/should punish } \\
\hline Police violated law & $.882(.006)^{*}$ & $.868(.007)^{*}$ & $.842(.006)^{*}$ \\
\hline Police engaged misconduct & $.919(.005)^{*}$ & $.907(.005)^{*}$ & $.912(.006)^{*}$ \\
\hline Police were fair (reverse) & $.797(.011)^{*}$ & $.767(.012)^{*}$ & $.707(.015)^{*}$ \\
\hline Police should be punished & $.964(.003)^{*}$ & $.950(.004)^{*}$ & $.942(.004)^{*}$ \\
\hline Police should not work street & $.914(.005)^{*}$ & $.916(.005)^{*}$ & $.902(.005)^{*}$ \\
\hline Police should be sued & $.780(.011)^{*}$ & $.821(.010)^{*}$ & $.849(.006)^{*}$ \\
\hline
\end{tabular}

$* p<.05$ 


\section{References}

Baker L, Wagner TH, Singer S, Bundorf MK (2003) Use of the internet and email for health care information: results from a national survey. JAMA 289:2400-2406

Balcetis E, Lassiter GD (eds) (2010) Social psychology of visual perception. Psychology Press, NY

Bargh J, Chartrand T (2000) Priming and automaticity research. In: Reis HT, Judd CM (eds) Handbook of research methods in social and personality psychology. Cambridge University Press, NY, pp 253-284

Beeghley L (2004) The structure of social stratification in the United States. Pearson, Allyn \& Bacon, Boston

Beetham D (1991) The legitimation of power. Humanities Press International, Atlantic Highlands

Bollen KA (1989) Structural equations with latent variables. Wiley, NY

Bollen KA, Long JS (eds) (1993) Testing structural equation models. Sage, Newbury Park

Bottoms A, Tankebe J (2012) Beyond procedural justice: a dialogic approach to legitimacy in criminal justice. J Crim Law Criminol 102:119-170

Box GE, Hunter WG, Hunter JS (2005) Statistics for experimenters: design, innovation, and discovery, 2nd edn. Wiley, NY

Braga AA (2008) Problem-oriented policing and crime prevention, 2nd edn. Lynne Rienner, Boulder

Brandl SG, Frank J, Worden RE, Bynum T (1994) Global and specific attitudes toward the police: disentangling the relationship. Justice Q 11:119-134

Brown TA (2006) Confirmatory factor analysis for applied research. Guilford, NY

Brown B, Benedict W (2002) Perceptions of the police: past findings, methodological issues, conceptual issues, and policy implications. Policing 25:543-580

Brunson RK (2007) Police don't like black people: African-American young men's accumulated police experiences. Criminol Pub Pol 6:71-101

Brunson RK, Miller J (2006) Young black men and urban policing in the United States. Brit J Criminol 46:613-640

Brunson RK, Weitzer R (2009) Police relations with black and white youths in different urban neighborhoods. Urb Aff Rev 44:858-885

Carr PJ, Napolitano L, Keating J (2007) We never call the cops and here is why: a qualitative examination of legal cynicism in three Philadelphia neighborhoods. Criminology 45:701-736

Coicaud J-M (2002) Legitimacy and politics: a contribution to the study of the political right and political responsibility. Cambridge University Press, Cambridge

Couper MP (2000) Web surveys: a review of issues and approaches. Pub Opin Q 64:464-494

Cronbach LJ (1951) Coefficient alpha and the internal structure of tests. Psychometrika 16:297-334

Dennis JM (2001) Are internet panels creating professional respondents? The benefits of online panels far outweigh the potential for panel effects. Mark Res Summer:34-38

Easton D (1975) A reassessment of the concept of political support. Br J Polit Sci 5:435-457

Erdley CA, D’Agostino P (1988) Cognitive and affective components of automatic priming effects. J Pers Soc Psychol 54:741-747

Fagan J (2002) Law, social science and racial profiling. Just Res Policy 4:104-129

Fagan J, Malkin V (2003) Theorizing community justice through community courts. Fordham Urb Law J 30:857-953

Fisher R (1926) The arrangement of field experiments. J Minist Agric G B 33:503-513

Fiske ST, Taylor SE (1991) Social cognition, 2nd edn. McGraw-Hill, NY

Fyfe JJ (2002) Too many missing cases: holes in our knowledge about police use of force. US Department of Justice, Washington

Gaertner SL, Mann J, Murrell A, Dovidio JF (1989) Reducing intergroup bias: the benefits of recategorization. J Pers Soc Psychol 57:239-249

Gallagher C, Maguire E, Mastrofski S, Reisig M (2001) The public image of the police. International Association of Chiefs of Police, Alexandria

Gardner MP (1983) Advertising effects on attributes recalled and criteria used for brand evaluations. J Consum Res 10:310-318

Gau J (2010) Basic principles and practices of structural equation modeling in criminal justice and criminology research. J Crim Just Educ 21:136-151

Gottfredson GD (1981) Schooling and delinquency. In: Martin SE, Sechrest LB, Redner R (eds) New directions in the rehabilitation of criminal offenders. Report of the panel on research on rehabilitative techniques. National Academy Press, Washington, DC

Gould J, Mastrofski SD (2001) The constitutionality of police searches. Paper presented at the annual meeting of the Midwest Political Science Association, Chicago 
Graham S, Lowery B (2007) Unconscious racial stereotypes about adolescent offenders. Law Hum Behav 28:483-504

Hastorf AH, Cantril H (1954) They saw a game: a case study. J Abnormal Psychol 49:129-134

Hawdon J (2008) Legitimacy, trust, social capital, and policing styles: a theoretical statement. Police Q 11:182-201

Herr PM (1989) Priming price: prior knowledge and context effects. J Consum Res 16:67-75

Higgins ET, Rholes WS, Jones CR (1977) Category accessibility and impression formation. J Exp Soc Psychol 13:141-154

Higgins ET, Bargh J, Lombardi W (1985) Nature of priming effects on categorization. J Exp Psychol Learn Memory Cogn 11:59-69

Hohl K, Bradford B, Stanko EA (2010) Influencing trust and confidence in the London Metropolitan Police. Br J Criminol 50:491-513

Hu L, Bentler PM (1999) Cutoff criteria for fit indexes in covariance structural analysis. Struct Equat Model $6: 1-55$

Jackson J, Bradford B (2009) Crime, policing and social order: on the expressive nature of public confidence in policing. Br J Sociol 60:493-521

Jackson J, Bradford B, Hough M, Myhill A, Quinton P, Tyler TR (2012) Why do people comply with the law? Legitimacy and the influence of legal institutions. Br J Criminol 52:1051-1071

Kim J-O, Mueller CW (1978) Introduction to factor analysis. Quantitative applications in the social sciences, paper 13. Sage, Newbury Park, CA

Kline R (2010) Principles and practice of structural equation modeling, 3rd edn. Guilford, NY

Krosnick JA, Chang LC (2001) A comparison of the random digit dialing telephone survey methodology with internet survey methodology as implemented by Knowledge Networks and Harris Interactive. Paper presented at conference of the American Association for Public Opinion Research. http://www. knowledgenetworks.com/ganp

Krueger AB, Malechkova J (2003) Education, poverty and terrorism: is there a causal connection. J Econ Perspect 17:119-144

Loftus EF, Doyle JM, Dysert J (2008) Eyewitness testimony: civil and criminal, 4th edn. Lexis Law Publishing, Charlottesville

Long JS (1983) Confirmatory factor analysis. Quantitative applications in the social sciences, paper 33. Sage, Newbury Park, CA

Mastrofski SD, Snipes J, Supina A (1996) Compliance on demand: the public's response to specific police requests. J Res Crime Delinq 33:269-305

Mazerolle L, Bennett S, Davis J, Sargeant E, Manning M (2012) Legitimacy in policing. Campbell systematic reviews

Mazerolle L, Antrobus E, Bennett S, Tyler TR (2013) Shaping citizen perceptions of police legitimacy: a randomized field trial of procedural justice. Criminology 51:33-64

McCauley C (2002) Psychological issues in understanding terrorism and the response to terrorism. In: Stout CE, Schwab K (eds) The psychology of terrorism, vol 3., ParegerWestport, CT, pp 33-65

McCluskey JD (2003) Police requests for compliance: coercive and procedurally just tactics. LFB Scholarly Publishing, NY

Meares T, Kahan D (1998) Law and (norms of) order in the inner city. Law Soc Rev 32:805-838

Moore M (1992) Problem-solving and community policing. In: Tonry M, Morris N (eds) Modern policing, crime and justice, vol 15. University of Chicago Press, Chicago, pp 99-158

Moore M (2002) Recognizing value in public policing. Police Executive Research Forum, Washington

Parsons T (1967) Some reflections on the place of force in social process. In: Parsons T (ed) Sociological theory and modern society. The Free Press, NY, pp 264-296

Paternoster R, Brame R, Bachman R, Sherman LW (1997) Do fair procedures matter? Law Soc Rev 17:457-479

Reisig MD (2010) Community and problem-oriented policing. In: Tonry M (ed) Crime and justice, vol 39. University of Chicago Press, Chicago, pp 2-53

Reisig MD, Chandek MS (2001) The effects of expectancy disconfirmation on outcome satisfaction in police-citizen interactions. Policing 21:88-99

Reisig MD, Bratton J, Gertz MG (2007) The construct validity and refinement of process-based policing measures. Crim Just Behav 34:1005-1028

Rosenbaum DP, Schuck A, Costello S, Hawkins DF, Ring M (2005) Attitudes toward the police: the effects of direct and vicarious experience. Police Q 8:343-365

Rossi P, Lipsey M, Freeman H (2004) Evaluation: a systematic approach, 7th edn. Sage, Thousand Oaks

Sarat A (1977) Studying American legal culture. Law Soc Rev 11:427-488 
Scheingold S (1974) The politics of rights, lawyers, public policy, and political change. Yale University Press, New Haven

Seron C, Pereira J, Kovath J (2006) Just punishment for police misconduct. Criminology 44:925-960

Shadish W, Cook T, Campbell D (2002) Experimental and quasi-experimental designs for generalized causal inference. Houghton Mifflin, Boston

Sherman LW (1999) Consent of the governed: police, democracy, and diversity. Paper presented at the conference in honor of Professor Menachem Amir, Institute of Criminology, Hebrew University of Jerusalem, Israel

Skitka LJ, Mullen E (2002) Understanding judgments of fairness in a real-world political context: a test of the value protection model of justice reasoning. Pers Soc Psychol Bull 28:588-597

Skitka LJ, Mullen E, Griffin T, Hutchinson S, Chamberlin B (2002) Dispositions, ideological scripts, or motivated correction? Understanding ideological differences in attributions for social problems. J Pers Soc Psychol 83:470-487

Skogan W (1990) Disorder and decline. The Free Press, NY

Skogan W, Frydl K (2004) Fairness and effectiveness in policing: the evidence. National Research Council, Washington

Skogan W, Hartnett S (1997) Community policing, Chicago style. Oxford University Press, NY

Skogan W, Meares TL (2004) Lawful policing. Ann Am Acad Polit Soc Sci 593:66-83

Skolnick JH, Fyfe JJ (1993) Above the law. The Free Press, NY

StataCorp (2011) Stata Release 12.0. StataCorp, College Station

Sunshine J, Tyler TR (2003) The role of procedural justice and legitimacy in shaping public support for policing. Law Soc Rev 37:555-589

Tankebe J (2009) Public cooperation with the police in Ghana: does procedural fairness matter? Criminology 47:1265-1293

Tankebe J (2013) Viewing things differently: the dimensions of public perceptions of police legitimacy. Criminology 51:103-135

Tyler TR (2003) Procedural justice, legitimacy, and the effective rule of law. In: Tonry M (ed) Crime and justice: a review of research, vol 30. University of Chicago Press, Chicago, pp 431-505

Tyler TR (2004) Enhancing police legitimacy. Ann Am Acad Polit Soc Sci 593:84-99

Tyler TR (2005) Policing in black and white: ethnic group differences in trust and confidence in the police. Police Q 8:322-342

Tyler TR (2006) Why people obey the law, 2nd edn. Princeton University Press, Princeton

Tyler TR, Fagan J (2008) Legitimacy and cooperation: why do people help the police fight crime in their communities? Ohio St J Crim Law 6:231-276

Tyler TR, Huo YJ (2002) Trust in the law: encouraging public cooperation with the police and courts. Russell Sage Foundation, NY

Tyler TR, Mitchell G (1994) Legitimacy and the empowerment of discretionary legal authority. Duke Law J 43:703-802

Tyler TR, Wakslak C (2004) Profiling and the legitimacy of the police: procedural justice, attributions of motive, and the acceptance of social authority. Criminology 42:13-42

Tyler TR, Boeckmann R, Smith HJ, Huo YJ (1997) Social justice in a diverse society. Westview, Boulder

U.S. National Advisory Commission on Civil Disorders (1968) Report of the national advisory commission on civil disorders. U.S. Government Printing Office, Washington, DC

Warren PY (2011) Perceptions of police disrespect during vehicle stops: a race-based analysis. Crime Delinq 57:356-376

Weisburd DL, Eck JE (2004) What can police do to reduce crime, disorder, and fear? Ann Am Acad Polit Soc Sci 593:42-65

Weitzer R, Tuch SA (2006) Race and policing in America: conflict and reform. Cambridge University Press, NY

Wells GL, Olson EA (2003) Eyewitness testimony. Ann Rev Psychol 54:277-295

Wolfinger R, Rosenstone SJ (1980) Who votes? Yale University Press, New Haven, CT 